Penelitian

\title{
Kesembuhan Skin Flap Rotasi pada Kucing dengan Perawatan Dry Dressing dan Moist Dressing secara Subjektif dan Objektif
}

\author{
The Wound Healing of Rotation Flap in Cats using Dry Dressing and \\ Moist Dressing by Subjective And Objective
}

\author{
Rusli Rusli', Amiruddin Amiruddin', Erwin Erwin'", Teuku Fadrial Karmil', Etriwati Etriwati², \\ M Nur Salim², Teuku Zahrial Helmi ${ }^{3}$ Rezeki Indah Sari ${ }^{4}$

\begin{abstract}
'Laboratorium Klinik Bedah dan Radiologi, Fakultas Kedokteran Hewan Universitas Syiah Kuala, Banda Aceh ${ }^{2}$ Laboratorium Patologi Fakultas Kedokteran Hewan Universitas Syiah Kuala, Banda Aceh

${ }^{3}$ Laboratorium Biokimia Fakultas Kedokteran Hewan Universitas Syiah Kuala, Banda Aceh

${ }^{4}$ Program Studi Pendidikan Dokter Hewan Fakultas Kedokteran Hewan Universitas Syiah Kuala, Banda Aceh

*Penulis untuk korespondensi: erwin2102@unsyiah.ac.id
\end{abstract} \\ Diterima 29 Maret 2021, Disetujui 31 Mei 2021
}

\begin{abstract}
ABSTRAK
Skin flap rotasi adalah flap berpola melengkung digunakan untuk penutupan defek berbentuk segitiga. Penelitian ini bertujuan mengetahui perbedaan kesembuhan skin flap rotasi pada kucing dengan perawatan dry dressing dan moist dressing secara subjektif dan objektif. Penelitian menggunakan 6 ekor kucing lokal jantan berumur 1-2 tahun, bobot badan 2-4 kg yang dibagi menjadi 2 kelompok perlakuan. Semua kucing dibuat luka berbentuk segitiga dengan ukuran 2 $\mathrm{cm}$ pada area right lateral abdomen untuk ditutup menggunakan skin flap rotasi. Kelompok I dirawat dengan dry dressing (K-I) dan kelompok II dirawat dengan moist dressing (K-II). Pengamatan subjektif meliputi perubahan warna kulit dan respon nyeri dilakukan pada hari ke-3, 6, 9 dan 12 setelah bedah serta uji pendarahan yang dilakukan pada hari ke-18 setelah bedah. Pengamatan objektif hari ke-18 setelah bedah untuk mengamati waktu absorpsi $\mathrm{NaCl} 0,9 \%$ dan waktu timbulnya dilatasi pupil setelah penyuntikan adrenalin. Kelompok dry dressing menunjukkan hasil yang baik pada hari ke-9 ditandai dengan warna kulit yang sama dengan kulit sekitar dan respon nyeri berkurang. Uji pendarahan menunjukkan darah segera keluar setelah insisi pada kedua kelompok perlakuaan. Waktu absorbsi $\mathrm{NaCl} 0,9 \%$ dan efek adrenalin lebih cepat pada kelompok dry dressing. Kesembuhan skin flap rotasi dengan perawatan dry dressing lebih cepat dibandingkan moist dressing
\end{abstract}

Kata kunci: dry dressing, moist dressing, skin flap rotasi

\begin{abstract}
Rotation flap is a curved pattern flap using to cover the defect in a triangle shape. This study were aimed to determine differences the wound healing of rotation flap in cats using dry dressing and moist dressing by subjective and objective. This study used 6 male local cats at 1-2 years old, weighing 3-4 kg, were divided into 2 treatment groups. All cats were made triangular defect of $2 \times 2 \mathrm{~cm}$ in the lateral abdomen area between os. sacrum and os. femur for rotation flap, then treatment using dry dressing (group I) and moist dressing (group II). Subjective observations covering skin discoloration and pain response that performed on the 3rd, 6th, 9th and 12th after rotation flap and the bleeding test that performed on the 18th after rotation flap. Objective observations were made on the 18th after rotation flap by observing the absorption time of $0,2 \mathrm{ml} \mathrm{NaCl} 0,9 \%$ and the onset of drug effect by observing the time of pupillary dilatation after $0,2 \mathrm{ml}$ adrenaline injection under the rotation flap. Dry dressing group show good result on the 9th day, which was characterized by similiar skin color with surrounding skin and reduced pain response. The bledding test showed blood came out immediately after incision in both groups. The objective observation by absorption time of 0,9 $\mathrm{NaCl}$ and the effects of adrenaline were faster in dry dressing group. The dry dressing group was healing faster than moist dressing group.
\end{abstract}

Keywords: dry dressing, moist dressing, rotation flap 


\section{PENDAHULUAN}

Luka didefinisikan sebagai hilang atau rusaknya kesatuan jaringan tubuh. Pada umumnya, kucing mengalami luka akibat trauma benda tajam dan benda tumpul, kecelakaan, gigitan hewan, luka bakar atau iritasi akibat bahan kimia. Penanganan luka insisi saat bedah yakni menggunakan jahitan berpola sehingga kedua tepi luka dapat dipertautkan (Richardson, 2004). Namun, kehilangan atau kerusakan kulit yang cukup luas menyebabkan luka tidak mampu menutup secara primer dan dibutuhkan jaringan penutup. Salah satu pilihan untuk menutupi luka yaitu pembuatan skin flap (Erwin et al., 2016 b).

Skin flap merupakan suatu teknik bedah penutupan luka menggunakan jaringan kulit dengan masih mempertahankan hubungan suplai darah. Berdasarkan cara pemindahannya, skin flap dikelompokkan menjadi local flaps dan distant flaps. Sementara itu, local flaps dibagi menjadi rotation flap, transposition flap, interpolation flap dan advancement flap. Skin flap rotasi adalah flap berpola melengkung dan dapat diputar/ rotasi, yakni sering digunakan untuk menutupi defek jaringan berbentuk segitiga (Nelissen \& White, 2014).

Penggunaan balutan luka (wound dressing) bertujuan untuk menutupi/ melindungi jaringan baru dan meminimalkan masuknya benda asing. Pemilihan dressing untuk menutupi area luka harus dilakukan secara tepat, efektif dan efesien bertujuan untuk mempercepat proses penyembuhan luka (Svensjo et al., 2000). Tipe balutan luka berdasarkan cara pembuatannya dibagi menjadi 2 kelompok, yaitu produk tenun (kain kasa, perban) dan produk non woven (lapisan tipis, komposit) (Mutia et al, 2011). Kasa steril merupakan dry dressing yang berfungsi untuk menyerap cairan pada luka. Perban framycetin sulfate adalah balutan luka kasa lanoparaffin mengandung antibiotik yaitu framycetin sulphate $1 \%$, berfungsi untuk menyediakan lingkungan luka yang moist (Wijaya, 2018). Kesembuhan luka secara klinis dievaluasi dengan menggunakan parameter subjektif dan parameter objektif (Erwin et al., 2016 ). Penelitian ini dilakukan untuk mengamati kesembuhan skin flap rotasi pada kucing dengan perawatan dry dressing dan moist dressing secara subjektif dan objektif.

\section{BAHAN DAN METODE}

\section{Ethical Approval}

Penelitian dilakukan setelah mendapat izin pelaksanaan penelitian dari Komisi Etik Fakultas
Kedokteran Hewan Universitas Syiah Kuala dengan nomor 49/KEPH/XI/2019.

\section{Prosedur Penelitian}

Semua kucing diadaptasikan dalam kandang individu selama 2 minggu disertai dengan pemberian antibiotik kombinasi amoxicillin dan clavulanic acid (Claneksi ${ }^{\circledR}$, Sanbe Farma, Indonesia) dosis $10 \mathrm{mg} / \mathrm{kg}$ $\mathrm{BB}$ per oral (PO) dan antiparasit ivermectin dosis $0,024 \mathrm{mg} / \mathrm{kg}$ BB secara subkutan (SC). Pemberian pakan komersil dan air minum dilakukan secara ad libitum. Sebelum bedah, kucing dipuasakan selama 8 jam. Kemudian dilakukan pencukuran rambut pada area lateral abdomen antara os. sacrum dan os. femur. Kucing dipremedikasi dengan atropin sulfate $0,04 \mathrm{mg} / \mathrm{kg}$ BB SC, dan dianastesi menggunakan kombinasi ketamin 10\% $10 \mathrm{mg} / \mathrm{kg}$ BB dan xylazine $2 \%$ $1 \mathrm{mg} / \mathrm{kg}$ BB IM.

Kucing yang telah teranastesi diposisikan ke right lateral recumbency. Desinfeksi area kulit menggunakan alkohol $70 \%$ dan povidone iodine. Selanjutnya dilakukan incisi kulit pada area lateral abdomen antara os. sacrum dan os. femur untuk pembuatan luka berbentuk segitiga seluas $2 \mathrm{~cm}$. Luka ditangani menggunakan skin flap rotasi dengan pembuatan flap semiserkuler berukuran 2 kali lebih panjang dari alas luka. Dilakukan undermining kulit di sekitar flap, kemudian retraksi dan rotasi bagian flap sehingga mampu untuk menutupi luka. Kulit dijahit dengan pola simple interupted menggunakan benang silk 3.0 USP (Silkam ${ }^{\circledast}$, Romed Medical, Indonesia).

Area skin flap rotasi ditutup menggunakan perban yang berbeda sesuai kelompok perlakuan. Kelompok I menggunakan kasa steril (dry dressing) dan kelompok II (moist dressing) menggunanakan framycetin sulfate (Sofra-Tulle ${ }^{\circledR}$, Pantheon UK Limited, Swidon, UK for Sanofi-Aventis, Thailand). Pergantian perban dilakukan pada hari ke- 3, 6, 9 dan 12 setelah bedah (Mathes et al., 2010). Perawatan luka setelah bedah menggunakan antibiotik Amoxicillin dan Clavulanic Acid $10 \mathrm{mg} / \mathrm{kg}$ BW (Claneksi ${ }^{\circledR}$, Sanbe Farma, Indonesia), Carprofen 2,2 $\mathrm{mg} / \mathrm{kg}$ BW (Rymadyl ${ }^{\circledR}$, Pfizer/Zoetis, USA) selama 7 hari dengan interval 2 kali sehari (Erwin et al., 2016 ${ }^{\mathrm{a}}$ ).

\section{Pengamatan Subjektif}

Parameter yang digunakan dalam pengamatan subjektif diantaranya adalah perubahan warna kulit, uji respon nyeri dan uji pendarahan. Pada hari ke- 3 , 6, 9 dan 12 setelah bedah dilakukan pengamatan perubahan warna kulit area skin flap rotasi dengan 
skoring (1) sama dengan kulit sekitar; (2) hiperimia; (3) iskemia; dan (4) nekrosis. Pada hari ke- 3, 6, 9 dan 12 setelah bedah dilakukan uji respon nyeri dengan memberi tusukan atau sentuhan pada area skin flap rotasi dengan skoring (1) tidak nyeri/sembuh; (2) nyeri/inflamasi; dan (3) tidak nyeri/nekrosis. Hari ke-18 setelah bedah dilakukan uji pendarahan melalui insisi ( $1 \mathrm{~mm}$ ) pada area kulit skin flap rotasi dengan skoring yaitu (1) darah segera keluar setelah incisi; dan (2) darah lama keluar setelah incisi (Erwin et al., 2016 ${ }^{\mathrm{a}}$ ).

\section{Pengamatan Objektif}

Pada hari ke-18 setelah bedah dilakukan pengamatan secara objektif yaitu kemampuan skin flap rotasi dalam mengabsorpsi $0,2 \mathrm{ml} \mathrm{NaCl} 0,9 \%$ dan mengamati waktu timbul dilatasi pupil dengan memberikan suntikan 0,2 $\mathrm{ml}$ adrenalin di bawah skin flap rotasi (Ijaz et al., 2012 dan Erwin et al., 2016 ${ }^{\text {a) }}$.

\section{Analisis Data}

Data hasil penelitian dari pengamatan subjektif dianalisis menggunakan ANAVA Multivariate disertai Post-Hoc Test uji Duncan dan pengamatan objektif dianalisis menggunakan uji $\mathrm{T}$ melalui bantuan program SPSS for Windows 24.0.

\section{HASIL}

\section{Pengamatan Subjektif}

\section{Perubahan Warna Kulit}

Dry dressing (kasa steril) dan moist dressing (SofraTulle ${ }^{\circledast}$, Pantheon UK Limited, Swidon, UK for SanofiAventis, Thailand) dapat digunakan untuk perawatan skin flap rotasi pada kucing. Secara makroskopis, kesembuhan skin flap rotasi lebih cepat pada kelompok dry dressing bila dibandingkan dengan kelompok moist dressing yang disajikan pada Gambar 1. Pengamatan hari ke-3, kedua kelompok perlakuan belum menunjukan perbedaan warna kulit. Hal tersebut terlihat dari warna kulit area skin flap rotasi tampak hiperemi dengan skoring $(2,00 \pm 0,00)$. Pengamatan hari ke-6, kelompok dry dressing warna kulit area skin flap rotasi sudah mulai menunjukkan kesamaan dengan kulit sekitar $(1,33 \pm 0,58)$, sedangkan kelompok moist dressing baru menunjukkan kesamaan dengan kulit sekitar pada hari ke-9 $(1,33 \pm 0,58)$. Berdasarkan hasil analisis varian, kelompok dry dressing dan kelompok moist dressing menunjukkan perbedaan signifikan $(P<0,05)$ terhadap perubahan warna kulit area skin flap rotasi. Rata-rata skoring perubahan warna kulit area skin flap rotasi disajikan pada Tabel 1.
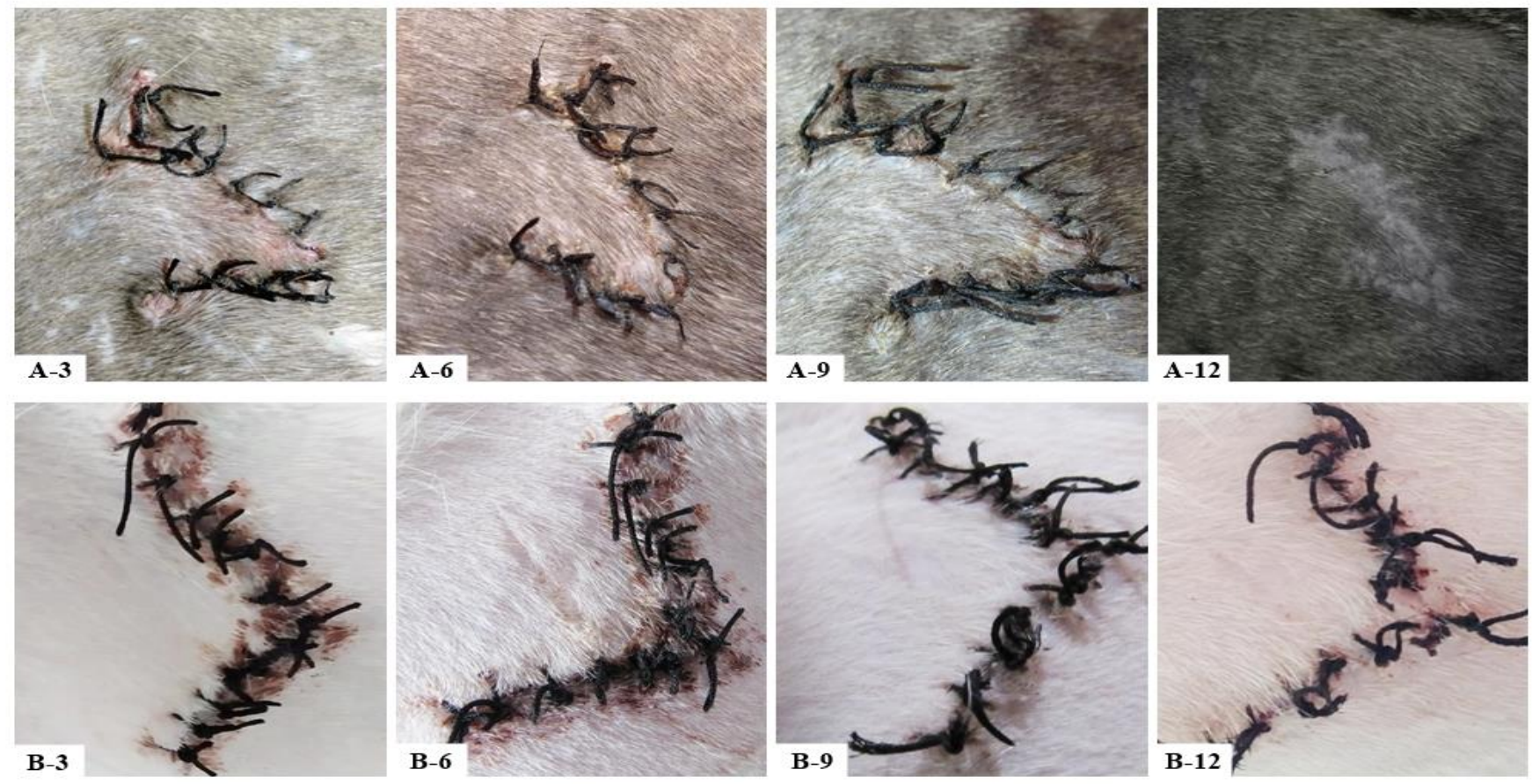

Gambar 1 Kesembuhan skin flap rotasi pada masing-masing waktu pengamatan. Kelompok I area skin flap rotasi dengan perawatan dry dressing pada hari-3 setelah bedah (A-3), hari-6 setelah bedah (A-6), hari-9 setelah bedah (A-9) dan hari-12 setelah bedah (A-12). Kelompok II area skin flap rotasi dengan perawatan moist dressing pada hari-3 setelah bedah (B-3), hari-6 setelah bedah (B-6), hari9 setelah bedah (B-9) dan hari-12 setelah bedah (B-12) 
Tabel 1 Rata-rata ( \pm SD) skoring perubahan warna kulit pada hari ke-3, 6, 9 dan 12 setelah skin flap rotasi dengan perawatan dry dressing dan moist dressing

\begin{tabular}{ccc}
\hline $\begin{array}{c}\text { Waktu Pengamatan } \\
\text { (hari) }\end{array}$ & Dry Dressing & Kelompok \\
\hline 3 & $2,00 \pm 0,00^{\mathrm{a}}$ & Moist Dressing \\
6 & $1,33 \pm 0,58^{\mathrm{b}}$ & $2,00 \pm 0,00^{\mathrm{a}}$ \\
9 & $1,00 \pm 0,00^{\mathrm{b}}$ & $2,00 \pm 0,00^{\mathrm{a}}$ \\
12 & $1,00 \pm 0,00^{\mathrm{b}}$ & $1,33 \pm 0,58^{\mathrm{b}}$ \\
\hline
\end{tabular}

Keterangan: ${ }^{\mathrm{a}, \mathrm{b}}$ superskrip yang berbeda pada kolom yang sama menunjukkan perbedaan yang signifikan $(P<0,05)$.

\section{Respon Nyeri}

Pengamatan respon nyeri hari ke-3 dengan skor $(2,00 \pm 0,00)$ pada kedua kelompok perlakuan, respon nyeri timbul akibat inflamasi pada area skin flap rotasi. Pengamatan hari ke-6 kelompok dry dressing, respon nyeri mulai berkurang dengan skoring $(1,33 \pm 0,58)$, sedangkan kelompok moist dressing respon nyeri mulai berkurang hari ke-9 dengan skoring $(1,33 \pm 0,58)$. Berdasarkan hasil analisis varian kelompok dry dressing dan kelompok moist dressing menunjukkan perbedaan signifikan $(P<0,05)$ terhadap respon nyeri pada area skin flap rotasi yang disajikan pada Tabel 2.

\section{Uji Pendarahan}

Berdasarkan uji pendarahan yang dilakukan pada hari ke-18 setelah bedah, kedua kelompok perlakuan tidak menunjukkan perbedaan signifikan $(P>0,05)$ dengan skoring $(1,00 \pm 0,00)$ yaitu darah segera keluar setelah incisi. Hal ini menandakan bahwa area skin flap rotasi mencapai proses proliferasi dengan baik.

\section{Pengamatan Objektif}

Hasil analisis varian, waktu absorpsi $0,2 \mathrm{ml} \mathrm{NaCl}$ $0,9 \%$ kelompok dry dressing (0,52 $\pm 0,04$ menit) menunjukan perbedaan signifikan dibandingkan kelompok moist dressing $(1,34 \pm 0,14$ menit $)(P<0,05)$. Waktu timbulnya dilatasi pupil setelah pemberian 0,2 $\mathrm{ml}$ adrenalin (2,14 $\pm 0,11$ menit) pada kelompok dry dressing dengan perbedaan signifikan dengan kelompok moist dressing $(4,38 \pm 0,14$ menit) $(\mathrm{P}<0,05)$. Waktu timbulnya reaksi obat simpatomimetik (adrenalin) lebih cepat pada kelompok dry dressing (Tabel 3).

\section{PEMBAHASAN}

Dari segi kelembapan luka, perban framycetin sulfate mempunyai kelebihan dalam memberikan lingkungan yang moist pada luka karena mengandung antibiotik (Wijaya, 2018). Meskipun banyak penelitian menunjukkan moist wound healing merupakan salah satu faktor yang berpengaruh positif terhadap penyembuhan luka (Svensjo et al., 2000 dan Kumar et al., 2004), namun dalam penelitian Jonkman et al. (1990) menunjukkan bahwa kelembapan optimal untuk penyembuhan luka yaitu keadaan gelatinous yang kelembapannya berada di antara lembap dan kering. Kelembapan luka yang berlebihan dapat menyebabkan terlepasnya graft dari wound bed dan terjadi maserasi pada area luka.

Perubahan warna kulit area skin flap rotasi menjadi hiperemi merupakan tahap awal proses inflamasi, yakni respon fisiologis tubuh terhadap luka dengan melakukan hemostatis dan vasodilatasi lokal. Vasodilatasi arteriola akan berdampak terhadap peningkatan suplai darah sehingga menyebabkan kulit bewarna merah dan bengkak pada area luka (Li et al., 2007). Inflamasi bertujuan mengeliminasi jaringan rusak dan mencegah terjadi infeksi invasif (Salim et al., 2018). Kelompok moist dressing, area skin flap rotasi tampak hiperemi sampai hari ke-6, sementara itu keadaan normal dari proses inflamasi dimulai sejak terjadinya luka sampai hari ke-5. Proses inflamasi dapat diperpanjang akibat terjadi infeksi, iritasi dan benda asing pada area luka. Kondisi luka dengan perawatan yang tidak baik berpengaruh terhadap lamanya proses inflamasi (Serhan et al., 2010).

Salah satu faktor lokal pada area luka adalah transudat yang berlebihan. Pada kelompok dry dressing 
Tabel 2 Rata-rata ( \pm SD) skoring respon nyeri pada hari ke-3, 6, 9 dan 12 setelah skin flap rotasi dengan perawatan dry dressing dan moist dressing

\begin{tabular}{ccc}
\hline $\begin{array}{c}\text { Waktu Pengamatan } \\
\text { (hari) }\end{array}$ & Kry Dressing & Kelompok \\
\hline 3 & $2,00 \pm 0,00^{\mathrm{a}}$ & Moist Dressing \\
6 & $1,33 \pm 0,58^{\mathrm{b}}$ & $2,00 \pm 0,00^{\mathrm{a}}$ \\
9 & $1,00 \pm 0,00^{\mathrm{b}}$ & $2,00 \pm 0,00^{\mathrm{a}}$ \\
12 & $1,00 \pm 0,00^{\mathrm{b}}$ & $1,33 \pm 0,58^{\mathrm{b}}$ \\
\hline
\end{tabular}

Keterangan: ${ }^{\mathrm{a}, \mathrm{b}}$ superskrip yang berbeda pada kolom yang sama menunjukkan perbedaan yang signifikan $(\mathrm{P}<0,05)$

Tabel 3 Waktu absorbsi $\mathrm{NaCl}$ dan dilatasi pupil setelah pemeberian adrenalin pada masing-masing kucing rotasi flap yang dirawat dengan dry dressing dan moist dressing

\begin{tabular}{ccccccc}
\hline \multirow{2}{*}{ Parameter } & \multicolumn{3}{c}{ Dry Dressing (menit) } & \multicolumn{3}{c}{ Moist Dressing (menit) } \\
& Kucing 1 & Kucing 2 & Kucing 3 & Kucing 1 & Kucing 2 & Kucing 3 \\
\hline Waktu Absorbsi & $0: 48$ & $0: 56$ & $0: 52$ & $1: 20$ & $1: 48$ & $1: 35$ \\
Dilatasi Pupil & $2: 02$ & $2: 24$ & $2: 15$ & $4: 28$ & $4: 53$ & $4: 34$ \\
\hline
\end{tabular}

tidak ditemukan adanya cairan di area skin flap rotasi, sedangkan pada kelompok moist dressing terlihat adanya cairan luka dalam jumlah minimal. Hal ini tentunya berefek pada luka menyebabkan jaringan luka sangat lembab dan cairan berkisar 25\% dari dressing (Bates-Jensen, 1997). Perban framycetin sulfate merupakan tulle grass berbahan katun yang dikombinasi parafin dan antimikrobial. Penggunaan tulle grass ini membutuhkan sekunder dressing karena tidak dapat menyerap cairan luka. Sementara itu, kasa steril merupakan balutan luka yang mampu menyerap cairan dalam jumlah sedikit sampai sedang (Wijaya, 2018). Proses penyembuhan luka sangatlah berkaitan dengan keseimbangan kelembapan dan kebutuhan untuk mengeluarkan cairan yang berlebihan pada area luka (Serhan et al., 2010).

Warna kulit area skin flap rotasi yang mulai menunjukkan kesamaan dengan kulit sekitar menandakan berlangsungnya proses proliferasi. Proses proliferasi dimulai hari ke-4 sampai hari ke-21 setelah terjadinya luka. Keberadaan sel fibroblas pada lapisan dermis distimulasi oleh makrofag dan berperan penting untuk mensintesis kolagen sebagai bahan dasar pembentuk jaringan granulasi. Adanya kolagen akan membentuk kapiler-kapiler baru (angiogenesis) pada area luka (Li et al., 2007). Munculnya krusta (kedua kelompok) berwarna kuning-hitam berasal dari serum yang mengering, merupakan karekterisasi proses proliferasi berupa formasi granulasi jaringan luka (Brett, 2008). Benang jahitan skin flap rotasi kelompok dry dressing dilepas hari ke-12 setelah bedah, sedangkan kelompok moist dresssing baru dilepas hari ke-16 setelah bedah. Penarikan kulit secara berlebihan saat pembuatan flap serta jumlah jahitan yang digunakan berpengaruh terhadap perubahan warna kulit. Untuk mencapai kesembuhan luka yang optimal sangat bergantung pada kondisi biologik masing-masing individu serta lokasi dan luas luka (Erwin et al., 2016 b).

Respon nyeri merupakan mekanisme protektif tubuh yang muncul akibat adanya jaringan rusak mengenai ujung syaraf nyeri. Kelompok moist dressing menunjukkan respon nyeri sampai hari ke6 , sedangkan kelompok dry dressing respon nyeri sudah mulai berkurang. Perbedaan skoring respon nyeri tersebut dipengaruhi oleh lamanya proses inflamasi pada masing-masing kelompok perlakuan. Hal ini karena pelepasan mediator kimia, seperti metabolit asam arakhidonat, produk leukosit, amina vasoaktif dan protease plasma (Erlina et al., 2007). Apabila tidak terjadi inflamasi, area luka tetap menjadi sumber nyeri dan menghambat proses penyembuhan luka (Ackermann, 2012).

Peningkatan prostaglandin menyebabkan terjadinya vasodilatasi disertai permeabilitas pembuluh darah area luka juga meningkat. Hal ini 
menyebabkan timbulnya pembengkakan dan nyeri pada awal terjadinya luka (Ackermann, 2012). Respon nyeri yang berlebihan dapat dihambat dengan pemberian Non Steroid Anti Inflamation Drugs (NSAID) melaluli hambatan sintesis mediator nyeri prostaglandin (Ou et al., 2019). Efek terapi NSAID berhubungan dengan mekanisme kerja penghambatan enzim siklooksigenase-1 (COX-1) dan enzim siklooksigenase-2 (COX-2). Kedua enzim tersebut dibutuhkan dalam biosintesis prostaglandin (Hasanah et al., 2011). Migrasi sel radang akan menurun ketika terjadi penekanaan prostaglandin, sehingga mengurangi vasodilatasi pembuluh darah serta berkurang respon nyeri dan pembengkakan pada area luka (Erwin et al., 2016a).

Salah satu indikator yang mempercepat proses penyembuhan luka adalah keberadaan neovaskularisasi (Murti et al., 2017). Melalui uji pendarahan, skin flap yang berhasil ditandai dengan tidak adanya kongesti vena (Erwin et al., 2016 ${ }^{\text {b }}$ ). Kongesti yaitu penimbunan darah didalam vena terjadi akibat aliran darah yang melambat atau bahkan berhenti (Ackermann, 2012). Apabila terlihat keluar darah yang bewarna gelap setelah insisi pada area skin flap rotasi, hal ini menandakan terjadinya kongesti vena (Eric, 2006; Tschoi et al., 2005).

Re-epitelisasi sangat berpengaruh terhadap penyembuhan luka, karena semakin cepat reepitelisasi terjadi maka semakin cepat pula luka tertutup. Re-epitelisasi terjadi melalui pergerakan sel-sel epitel dari tepian jaringan bebas menuju jaringan rusak pada permukaan kulit (Murti et al., 2017). Percepatan waktu absorpsi dan efek obat juga dipengaruhi oleh neovaskularisasi. Banyaknya sel epitel yang rusak menyebabkan pertumbuhan jaringan ikat juga berlebihan sehingga mempengaruhi neovaskularisasi (Erwin et al., $2016^{\text {b }}$ ). Setelah diabsorpsi obat didistribusi melalui aliran darah sehingga menimbulkan respon klinik pada organ tubuh.

Adrenalin merupakan obat simpatomimetik yakni menimbulkan efek simpatis, berupa dilatasi pupil, peningkatan denyut jantung dan tekanan darah serta indra pengelihatan dan pendengaran menjadi lebih waspada. Aspek farmakologi pemberian obat kedalam tubuh melalui dua fase, yaitu farmakokinetik dan farmakodinamik. Farmakokinetik berperan untuk mengkarakterisasi nasib obat didalam tubuh, obat yang diberikan diabsorpsi, distribusi, metabolisme dan eksresi oleh tubuh. Sedangkan farmakodinamik memperlajari tentang mekanisme kerja obat sampai menimbulkan respon klinik (Erwin et al., 2016 ).
Kesimpulan penelitian ini adalah kesembuhan skin flap rotasi pada kucing dengan perawatan dry dressing lebih cepat dibandingkan moist dressing berdasarkan pengamatan secara subjektif dan objektif. Namun masih diperlukan penelitian lanjutan untuk mengaplikasikan jenis-jenis dressing lainnya dalam perawatan luka skin flap.

\section{UCAPAN TERIMA KASIH}

Penulis mengucapkan Terima Kasih kepada Rektor Universitas Syiah Kuala melalui dana penelitian Penelitian Lektor Kepala Sumber Dana PNBP Universitas Syiah Kuala dengan Nomor Kontrak 85/UN11.2.1/PT.01.03/PNBP/2021.

"Penulis menyatakan tidak ada konflik kepentingan dengan pihak pihak yang terkait dalam penelitian ini".

\section{DAFTAR PUSTAKA}

Ackermann MR. 2012. Inflammation and healing. In: Zachary, J.F. and McGavin, M.D., editors. Pathology Basis of Veterinary Disease. 5th ed. Missouri (US): Academic Press Elsevier Mosby.

Bates-Jensen BM. 1997. The pressure sore status tool a few thousand assessments later. Adv. Wound. Care 10(5):65-73.

Brett D. 2008. A review of collagen and collagenbased wound dressings. Wounds 20(12):347-356.

Eric RP. 2006. Head and facial wounds in dog dan cat. Vet. Clin. Small. Anim. 36(4):793-817.

Erlina R, Indah AY. 2007. Efek antiinflamasi ekdtrak etanol kunyit (Curcuma domestica Val.) pada tikus putih jantan galur wistar. Jurnal Sains dan Teknologi Farmasi. 12(2):112-115.

${ }^{a}$ Erwin E, Gunanti, Haryani E, Noviana D. 2016. Subjective and objective observation of skin graft recovery on Indonesian local cat with different periods of transplantation time. Vet. World 9(5): 481-486.

bErwin E, Noviana D, Gunanti, Putra IGANAE. 2016. Kesembuhan skin flap h-plasty dan linear closure untuk penutupan luka area lateral thoraks. Jurnal Sain Veteriner 34(2):203-209.

Hasanah AY, Nazaruddin F, Febrina E, Zuhrotun A. 2011. Analisis kandugan minyak atsiri dan uji aktivitas antiinflamasi ekstrak rimpang kencur (Kaempferia galanga L.). Jurnal Matematika dan Sains. 16(3):147-152. 
ljaz MS, Mahmood AK, Ahmad N, Khan MA, Farooq U. 2012. Viability of split thickness autogenous skin transplantation in canine distal limb reconstruction an experimental evaluation. Pak. Vet. J. 32(2):193-196.

Jonkman MF, Hoeksma EA, Nieuwenhuis P. 1990. Accelerated epithelialization under a highly vapor-permeable wound dressing is associated with increased precipitation of fibrin (ogen) and fibronectin. J. Invest. Dermatol. 94(4):477-484.

Kumar S, Wong PF, Leaper DJ. 2004. What is new in wound healing?. Turk. J. Med. Sci. 34:147-60.

Li J, Chen J, Kirsner R. 2007. Pathophysiology of acute wound healing. Clin Dermatol. 25(1):9-18.

Mathes DW, Noldan M, Graves S, Schlenker R, Miwongtum T, Storb T. 2010. A preclinical canine model for composite tissue transplantation. Journal Reconstruction Microsurgery. 26(3):201-207.

Murti DA, Salim MN, Sabri M. 2017. Efektifitas salep getah jarak pagar (Jatropha curcas L) pada fase epitelisasi penyembuhan luka sayat kulit mencit (Mus musculus) dengan pewarnaan masson trichrome. JIMVET. (3):465-472.

Mutia T, Eriningsih R, Safitri R. 2011. Membran alginat sebagai pembalut luka primer dan media penyampaian obat topikal untuk luka yang terinfeksi. Jurnal Riset Industri. 5(2):161-174.

Nelissen, P. and White, D. 2014. Flaps and graft. In: Langley-Hobbs, S.J., Demetriou, J.L. and Ladlow,
J.F., editors. Feline Soft Tissue and General Surgery. St. Louis (US): British Library Cataloguing in Publication Data Saunders Elsivier. Pp 195-207.

Ou Z, Zhao J, Zhu L, Huang L, Ma Y, Ma C, Lou C, Zhu Z, Yuan Z, Wu J, Li R, Yi J. 2019. Antiinflammatory effect and potential mechanism betulinic acid on $\lambda$-carrageenan-induced paw edema in mice. Biomedicine and Pharmacotherapy. 118:1-4.

Richardson M. 2004. Procedures for cleansing, closing and covering acute wounds. Nursing Times Journal. 100(4):54-59.

Salim MN, Masyitha D, Haris A, Balqis U, Iskandar CD, Hambal M, Darmawi. 2018. Anti-inflammatory activity of Jatropha curcas Linn. Latex in cream formulation on CD68 expression in mice skin wound. Vet. World. 11(2):99-103.

Serhan CN, Ward PA, Gilroy DW. 2010. Fundamentals of Inflamation. New York (US): Cambridge University Press.

Svensjo T, Pomahac B, Yao F, Slama J. 2000. Accelerated healing of full-thickness skin wounds in a wet environment. Plast. Reconstr. Surg. 106(3):602-612.

Tschoi M, Hoy FA, Granick M.S. 2005. Skin Flap. Clinics in Plastic Surgery. 32(2):261-273.

Wijaya MS. 2018. Perawatan Luka dengan Pendekatan Multidisiplin. Yogyakarta (ID): Penerbit ANDI. 